\title{
Articles
}

\section{Legal Harmonization Through Interfederal Cooperation: A Comparison of the Interfederal Harmonization of Law Through Uniform Law Conferences and Executive Intergovernmental Conferences}

\author{
By Anika Klafki*
}

\begin{abstract}
Modern federations are faced with the challenge of cross-state as well as cross-nation economic activities and with the ever-increasing mobility of society. This has not only promoted international law, but has also created the need for harmonized laws throughout federations within the competence areas of the states. Diverse laws within federal systems may increase transaction costs, cause delays, and lead to jurisdictional conflicts for nationwide or cross-state transactions. In order to preserve federalism, and therefore prevent an ever-advancing process of centralization, interfederal legal harmonization promoted by the states themselves is crucial. There are two distinct methods of legal harmonization of state laws: (1) harmonization by "Uniform Law Conferences," which are in principle run by lawyers and thus independent, to a certain extent, from the influence of policy makers; and (2) harmonization by executive intergovernmental conferences. These two distinct models of interfederal legal harmonization will be analyzed and evaluated with regard to efficiency, compatibility with democratic principles, transparency, and accountability in a comparative legal study of the harmonization processes. This Article will scrutinize the federal systems of the United States and Canada, on the one hand, as well as those of Germany and Austria, on the other hand. The study will reveal that the efficiency of interfederal legal harmonization increases with the level of intergovernmental integration through the participation of government officials and their staff.
\end{abstract}

\footnotetext{
*Dr. Anika Klafki, LL.B. (Bucerius Law School) is a Senior Research Assistant at the Chair of Public Law, Administrative Science and Comparative Law of Prof. Dr. Hermann Pünder, LL.M. (lowa) at Bucerius Law School, Hamburg, Germany.
} 


\section{A. Introduction and Outline of the Comparative Study}

Federal systems all around the world are confronted with the task of how to distribute power adequately between the federal and the state levels. This is a difficult task as the constituent states have developed historically and are not necessarily structured to ensure perfect regulatory problem-solving capacities. ${ }^{1}$ Their territories often fail to fully address certain policy problems. ${ }^{2}$ Sometimes policy problems only arise in a specific part of a state; at other times, a problem affects several states within a federation. Perfect mapping is thus impossible. In most federal systems, the federal constitution provides a certain repartition of competencies in order to balance power vertically in an effective manner. ${ }^{3}$ Despite the rigidity of constitutional norms, in constitutional reality, federal powers are in constant motion when meeting social needs. Federal systems are therefore dynamic and sway between decentralization and centralization in reaction to social developments both within and outside the nation. ${ }^{4}$

Globalization has led to cross-state and cross-nation economic activity, as well as the increased mobility of populations, businesses, and goods. This leads to increasing international legislative action. Transnational cooperation also generates the need for legal unification of state laws across federalized states. ${ }^{5}$ Even in areas which are not yet the subject matter of international conventions, legal harmonization can be advantageous. Diverse laws within a federation can increase transaction costs, cause delays, and lead to jurisdictional conflicts for nationwide or cross-state transactions. ${ }^{6}$ This raises the need for the legal harmonization of state laws and often points toward further centralization. ${ }^{7}$ In many federations, states have started to harmonize their laws informally through

${ }^{1}$ Cf. W. Brooke Graves, Uniform State Action: A Possible Substitute for Centralization 9-10 (1934); William H. Riker, Federalism: OrIGIN, Operation, SigNificANCE 15 (1964); Jacob S. Ziegel, Harmonization of Private Laws in Federal Systems of Government: Canada, the USA, and Australia, in MAKING COMMERCIAL LAW: ESSAYS IN HONOR OF ROY GOODE 131, 132 (Ross Cranston ed., 1997).

${ }^{2}$ Cf. Gordon Tullock, Federalism: Problems of Scale, 6 PUв. CHOICE 19 et seq. (1969).

${ }^{3}$ For the difficulties of the allocation of power, see Daniel Halberstam, Federalism: Theory, Policy, Law, in THE OXFORD HandBook of Comparative Constitutional LaW 576, 593-95 (Michel Rosenfeld \& András Sajó eds., 2012).

${ }^{4}$ Arthur Benz, Dimensions and Dynamics of Federal Regimes, in Federal Dynamics: ContinUity, Change, AND the VARIETIES OF FEDeralism 70 et seq. (Arthur Benz \& Jörg Broschek eds., 2013).

${ }^{5}$ Daniel Halberstam \& Mathias Reimann, Federalism and Legal Unification: Comparing Methods, Results, and Explanations Across 20 Systems, in FEDERALISM AND LEGAL UNIFICATION: A COMPARATIVE EMPIRICAL INVESTIGATION OF TWENTY SYSTEMS 3, 26-29 (Daniel Halberstam \& Mathias Reimann eds., 2014).

${ }^{6}$ Ziegel, supra note 1, at 135 et seq. For Canada specifically, see W. H. Hurlburt, Uniform Law Conference of Canada, 5 Commonwealth L. Bull. 250 (1979); Arthur Close, The Uniform Law Conference and the Harmonization of Law in Canada, 40 U.B.C.L. REv. 535, 541 (2007).

${ }^{7}$ Cf. GRAVES, supra note 1 , at 3-10. 
interfederal institutions in order to satisfy the need for unification without losing power to the central level. ${ }^{8}$

The following comparative analysis will focus on interfederal institutions with regard to: (1) how effectively they harmonize laws; (2) their compatibility with democratic principles; (3) their transparency; and (4) the accountability of their decision-making. I submit that there is a trade-off between effectiveness and democratic legitimacy, on the one hand, as well as another trade-off between transparency and accountability of interfederal legal harmonization, on the other hand. Two forms of interfederal legal harmonization will be contrasted with each other: (1) legal unification by Uniform Law Conferences in the U.S. and Canada; and (2) legal unification by executive intergovernmental conferences by governors and ministers in Germany and Austria. In order to draw a comprehensive picture of the interfederal harmonization process in the different federal systems, I will first provide a brief overview of the federal system in the respective countries, particularly with regard to the need for interfederal cooperation. ${ }^{9}$ Then, I will explain the institutional, organizational, and procedural rules, as well as the assertiveness of the informal interfederal harmonizing bodies. On this basis, I will compare the two modes of interfederal harmonization.

\section{B. Legal Harmonization by Uniform Law Conferences}

An important characteristic of Uniform Law Conferences, in contrast to executive intergovernmental conferences, is that they are not run by politicians or public servants. Instead they are staffed by independent lawyers who are appointed by the states to discuss model laws in areas where legal harmonization or even unification is deemed necessary. Uniform Law Commissions, thus, draw their legitimacy from their specialist legal expertise. The first Uniform Law Conference was founded in the late 19th century by the American Bar Association ${ }^{10}$ and was the role model for its Canadian counterpart, the Uniform Law Conference of Canada, founded at the beginning of the 20th century. Even though the Canadian Uniform Law Conference was based on the U.S. Uniform Law Commission, these two interfederal institutions have developed differently with regard to their staffing, their level of transparency, and the outcome of their work. Recently, Mexico also established a Mexican Centre of Uniform Law. But, as the institution is relatively new and deals with issues

\footnotetext{
${ }^{8}$ Halberstam \& Reimann, supra note 5, at 15-17.

${ }^{9}$ We will see that the legal reality of federalism in the analyzed systems is often very different from the constitutional outset.

${ }^{10}$ For the history of the Uniform Law Commission, see Vaughn C. Ball, The Organized Movement for Uniform State Legislation, 9 OHIO ST. L.J. 551 et seq. (1948); WALTER P. ARMSTRONG, A CENTURY OF SERVICE: A CentenNial HISTORY OF THE NATIONAL Conference of Commissioners on Uniform State LaWs 11 et seq. (1991); Robert A. Stein, Strengthening Federalism: The Uniform State Law Movement in the United States, 99 MINN. L. REV. 2253 et seq. (2015).
} 
concerning the relation between the federal and the state level rather than formulating model laws for interfederal harmonization purposes, it is not examined in this study. ${ }^{11}$

\section{Overview of the Dualistic Federal Systems in the U.S. and Canada}

In order to understand the different developments of the interfederal harmonization conferences in Canada and the U.S., I will briefly describe their constitutional background. One of the most obvious differences is that the U.S. system is presidential, and therefore provides for a strict distinction between legislative and executive functions. In the parliamentary cabinet government system of Canada, legislative and executive powers are more intertwined. ${ }^{12}$ Both systems are federations; nevertheless, a closer look reveals that the systems differ considerably with regard to their aims, competence distribution, their development in constitutional reality, and the functions of the senate on the federal level.

The federal system of the U.S., on the one hand, originates from the desire to transform a young confederation of independent states into a militarily and economically more successful nation. ${ }^{13}$ In order to persuade the states to build a closer union, a dual federalism model was established where the federation and the states are both sovereign with regard to the territorial and political areas committed to them. ${ }^{14}$ In order to retain as much power as possible at the state level, Article I, Section 8 of the U.S. Constitution devolves only comparatively few competencies to the federal level. Furthermore, residual competencies were explicitly assigned to the states by the Tenth Amendment. To that effect, the Constitution accepts a high degree of legal diversity in the federation. ${ }^{15}$

\footnotetext{
${ }^{11}$ For a short overview of the Centre's activities, see Close, supra note 6, at 546.

12 For a good overview of the effects of presidential and parliamentary systems in constitutional reality, see generally Aalt Willem Heringa \& Philipp KüVer, Constitutions Compared: An Introduction to Comparative Constitutional LAW 20 et seq. (3d ed. 2012).

${ }^{13}$ The Federalist No. 28 (Alexander Hamilton), No. 51 (James Madison). See also RIKeR, supra note 1, at 16 et seq.; Akhil Reed Amar, Of Sovereignty and Federalism, 96 YALE L.J. 1425, 1446 et seq. (1987); Deborah Jones Merritt, The Guarantee Clause and State Autonomy: Federalism for a Third Century, 88 CoLUM. L. REV. 1, 3 (1988).

${ }^{14}$ See 1 Alexis De Tocqueville, Chapter 8, in Democracy In AmERICA 114, 116 (New York 1948). See also McCulloch v. Maryland, 17 U.S. 316, 410 (1819) ("In America, the powers of sovereignty are divided between the Government of the Union and those of the States. They are each sovereign with respect to the objects committed to it, and neither sovereign with respect to the objects committed to the other.").

15 James R. Maxeiner, United States Federalism: Harmony Without Unity, in FEDERALISM AND LEGAL UNIFICATION: A COMPARATIVE EMPIRICAL INVESTIGATION OF TWENTY SYSTEMS 491, 500 (Daniel Halberstam \& Mathias Reimann eds., 2014).
} 
Canadian federalism, on the other hand, is characterized by the aim to unite a society that was, and is still today, divided on the basis of linguistic and ethnic differences. ${ }^{16}$ Canada is thus often described as a multinational, bilingual federation in which the power-sharing arrangement between the federal and the provincial level serves the purpose of accommodating cultural diversity. ${ }^{17}$ Canadian constitutional law consists of codified acts and uncodified traditions and conventions. Canada was divided by the Constitution Act of 1791 into Lower Canada, which was predominantly French-speaking and adopted the French civil law regime, and Upper Canada, which was predominantly English-speaking and adopted the common law system. ${ }^{18}$ The Constitution Act of 1867 formed the basis for Canada's modern federal system by forming provinces and splitting the legislative powers between the central level and the provinces. The former territory of the French-speaking Lower Canada became part of the Quebec province, which retained the civil law tradition in private law. The other provinces legislate on a common law basis. Furthermore, the Canadian constitutional law also recognizes territories ${ }^{19}$-but the present study shall ignore these as their role is of no great significance to the topic of interfederal legal harmonization. The exclusive legislative powers of the federal level are listed in Section 91 of the Constitution Act of 1867, while Sections 92 et seq. stipulate the competencies of the provincial legislatures, which are predominantly assigned to the provinces exclusively. ${ }^{20}$ Notably, the provinces are competent for "Property and Civil Rights". ${ }^{21}$ All the same, Section 94 of the Constitution Act of 1867 gave the federal parliament the power to make provisions for the "Uniformity of all or any of the Laws relative to Property and Civil Rights." ${ }^{22}$ Furthermore, in contrast to the U.S., the residual competence is allocated to the federal level. ${ }^{23}$ Hence, the founding fathers initially intended for a higher level of centralization in Canada than in the U.S. ${ }^{24}$

\footnotetext{
${ }^{16}$ Aline Grenon, Unification of Laws in Federal Systems: The Canadian Model, in Federalism AND Legal Unification: A COMPARATIVE EMPIRICAL INVESTIGATION OF TWENTY SYSTEMS 169, 171 (Daniel Halberstam \& Mathias Reimann eds., 2014).

${ }^{17}$ Cf. Michael Burgess, Comparative federalism: Theory and Practice 120-23 (2006).

${ }^{18}$ Grenon, supra note 16 , at 170.

${ }^{19}$ Peter W. Hogg, Constitutional Law of Canada 196 et seq. (2d ed. 1985).

${ }^{20}$ There are only four concurrent powers in Sections 92A and 94A of the Constitution Act of 1867 for the export of non-renewable natural resources, forestry resources, electrical energy, and pensions. For details, see Grenon, supra note 16 , at 171 .

${ }^{21}$ Constitution Act, 1867, § 91, no. 13 (Can.).

${ }^{22} / d . \S 94$.

${ }^{23} / d . \S 91$.

${ }^{24}$ For more details, see Hogg, supra note 19, at 88 et seq.; PAtRick Monahan \& BYron SHAW, Constitutional LaW 11, 109 et seq. (4th ed. 2013).
} 
In fact, the constitutional realities in Canada and the U.S. developed differently. In the U.S., the central level gains more and more powers through the implied powers doctrine. ${ }^{25}$ Moreover, on the basis of the Necessary and Proper Clause, the federal level has many competencies, flanked by the permissive interpretation of these federal competencies by the Supreme Court. ${ }^{26}$ Furthermore, cooperative structures between the federal level and the states evolved with the reform projects of the New Deal in $1930^{27}$ and the grants-in-aid programs of the 1960 s. $^{28}$ Thus, despite the rigidity of the U.S. Constitution, a strong trend towards centralization and cooperation prevailed in the past century. ${ }^{29}$

In contrast, the Canadian federal power to formulate uniform laws in Section 94 of the Constitution Act of 1867 became a dead letter because the provincial legislatures never adopted the federally created laws. ${ }^{30}$ Furthermore, the constitutional judicature consistently emphasizes the division of powers, strictly guarding the federal principle. ${ }^{31}$ Therefore, the Canadian judiciary has created a much more decentralized federal system in Canada than that found in the U.S. even though the constitutional texts of the two countries suggest the opposite. ${ }^{32}$ Nevertheless, in comparison with other nations, like Germany and

\footnotetext{
25 McCulloch, 17 U.S. at 406. See 1 Laurence H. Tribe, American Constitutional LaW § 5.3 (3d ed. 2000).

${ }^{26}$ Edward S. Corwin, The Passing of Dual Federalism, 36 VA. L. ReV. 1, 3-4 (1950); Rudolf H. Heimanson, Federalism and the Uniform Law Movement, 6 N.Y.L.F. 161, 163 (1960); Maxeiner, supra note 15, at 496 et seq.; GORDON Tullock, THe NeW Federalist 127 et seq. (1994); A. Brooke Overby, Our New Commercial Law Federalism, 76 TEMP. L. REV. 297, 302 et seq. (2003); Carlyle Conwell Ring, Jr., A New Era: Cooperative Federalism-Through the Uniform State Laws Process, 33 HAMLINE L. ReV. 375, 378 (2010). For the centralization process in commerce law, see United States v. Darby, 312 U.S. 100, 118 (1941); Garcia v. San Antonio Metro. Transit Auth., 469 U.S. 528, 551-56 (1985); Gonzales v. Raich, 545 U.S. 1 (2005). For a summary of the development of the judicature of the Supreme Court, see Robert Schütze, From Dual to Cooperative Federalism: The Changing Structure of European LaW 84 et seq. (2009).

27 Graves, supra note 1, at 19-20; William ANDERSON, FEderalism AND INTERGOVERNMENTAL ReLATIONS: A BUdGET OF SUGGESTIONS FOR RESEARCH 91 et seq., 107, 118 et seq., 144 et seq. (1946); Daniel J. Elazar, Cooperative Federalism, in

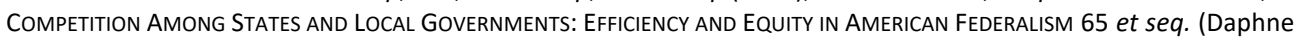
A. Kenyon \& John Kincaid eds., 1991); SCHÜTZE, supra note 26, at 123.

${ }^{28}$ Corwin, supra note 266, at 17 et seq.; Roderick M. Hills, Jr., The Political Economy of Cooperative Federalism: Why State Autonomy Makes Sense and "Dual Sovereignty" Doesn't, 96 MICH. L. REV. 813, 815 (1998); SCHÜTZE, supra note 26, at 79 et seq. For the admissibility of grant-in-aid programs, see Mass. v. Mellon, 262 U.S. 477, 482 (1923).

${ }^{29}$ For a critical analysis of this development, see AdVISORY COMM'N ON INTERGOVERNMENTAL REL., THE FEDERAL ROLE IN the Federal System: The Dynamics of GROWTH S. 4 et seq. (1981); Michael S. Greve, Against Cooperative Federalism, 70 MISS. L.J. 557, 577 (2000).

30 The Canadian Supreme Court sees its role as the guardian of federalism. See GREg TAYLOR, CHARACTERISATION IN FEDERATIONS: Six COUNTRIES COMPARED 27 et seq. (2006); Close, supra note 6, at 536 et seq.

31 See MONAHAN \& SHAW, supra note 24, at 241 et seq.; Ziegel, supra note 1, at 137; TAYLOR, supra note 30, at 29 et seq.; Grenon, supra note 16, at 175.

32 TAYLOR, supra note 30, at 29 et seq.; MONAHAN \& SHAW, supra note 24, at $11 \mathrm{f} ., 241$ et seq.; Grenon, supra note 16 , at 175 .
} 
Austria, the U.S. system must also be characterized as highly federalized. Due to the long history and firm roots of federalism in Canada and the U.S., there is a considerable aversion to further centralization. In both systems, the senate has no satisfactory means to protect or even represent the institutional self-interest of the states as they are chosen independently from the states' governments. ${ }^{33}$ The Senate in the U.S. is elected directly by the people, ${ }^{34}$ while in Canada, the senators are appointed centrally by the general governor on the proposal of the Prime Minister. ${ }^{35}$ Hence, for the senators of both systems, there is no political incentive to protect the competencies of states or to foster harmonizing agreements between them. As a result, the need for interfederal legal harmonization is steadily growing in fields which affect social mobility-for example, family law-nationwide or supra-regional business transactions-for example, corporate law-and the ambit of international treaties.

\section{Uniform Law Conferences in U.S. and Canada}

In order to meet the need for interfederal legal harmonization, the American Bar Association founded the National Conference of Commissioners on Uniform State Laws-which is known today as the Uniform Law Commission. ${ }^{36}$ According to its constitution, "it is the purpose of the Conference to promote uniformity in the law among the several States on subjects as to which uniformity is desirable and practicable." ${ }^{37}$ Imitating the Uniform Law Commission of the U.S., the Canadian Bar Association established the Conference of Commissioners on Uniformity of Laws throughout Canada, now known as the Uniform Law Conference of Canada. ${ }^{38}$ The Uniform Law Commission was one of the first interfederal bodies of the U.S. and is managed by lawyers, law professors, and judges who are appointed by the states. The Canadian Uniform Law Conference is also managed by legal professionals selected by the

\footnotetext{
${ }^{33}$ For a comparative political science perspective, see Fritz W. Scharpf, The Joint-Decision Trap Revisited, $44 \mathrm{~J}$. COMMON MKT. STUD. 845, 847 f. (2006).

${ }^{34}$ U.S. CONST. amend. XVII, § 3(1).

${ }^{35}$ Constitution Act, 1867, §§ 24, 26, 27, 32 (Can.).

${ }^{36}$ For the history of the Uniform Law Commission see Ball, supra note 10, at 551 et seq.; ARMSTRONG, supra note 10, at 11 et seq.; Stein, supra note 10, at 2253 et seq.

${ }^{37}$ Constitution art. 1, § 1.2 (Unif. Law Comm’n 2018).

${ }^{38}$ Ziegel, supra note 1 , at 141.
} 
provinces, territories, and the federal level of Canada. ${ }^{39}$ The Uniform Law Conferences in both countries are funded by the participating jurisdictions. ${ }^{40}$

With regard to the degree of transparency and the staffing of the conferences, there are significant differences between the U.S. and Canada. The organization and the working procedure of the U.S. Uniform Law Commission is elaborately regulated by its publicly accessible constitution and bylaws. ${ }^{41}$ Each jurisdiction determines the process of appointment and the number of commissioners. ${ }^{42}$ In most jurisdictions, the governor appoints the commissioners. ${ }^{43}$ Furthermore, every state appoints a principal administrative officer of the state legislative reference bureau or an equivalent agency as an "associate member." ${ }^{44}$ The only requirement that the constitution of the Uniform Law Commission sets for appointing commissioners or associate members is that the appointee must be a member of the bar of a state. ${ }^{45}$ The size of a state commission is unlimited as each jurisdiction only has one indivisible vote during the annual conferences.

In contrast to its U.S. counterpart, the Uniform Law Conference of Canada operated without a written constitution for many years, allowing itself much more flexibility through its informality. ${ }^{46} \mathrm{~A}$ formal written constitution and bylaws were only adopted in $1996 .{ }^{47}$ Similar to the U.S., each jurisdiction determines the process of appointment and the number of commissioners. Generally, they are appointed by the executive. ${ }^{48}$ The conference consists

\footnotetext{
39 CONSTITUTION AND ByLAWS pmbl. § D (UNIF. LAW CONF. CAN. 1996). Initially, it was only comprised of the provincial delegations, but it was enlarged through the addition of the federal delegation and delegations of the territories. See Close, supra note 6, at 547.

${ }^{40}$ See ConstitUTION AND BYLAWS, supra note 39, pt. 11, § 22, VII. Yet, the modest funding policy of the different jurisdictions has caused major problems for the ULCC. See Grenon, supra note 16, at 184 . See also Hurlburt, supra note 6 , at 248 .

${ }^{41}$ CONSTITUTION, supra note 37

42 Most states issued special laws concerning the nomination of the commissioners. But, if there is no state regulation, the bar may appoint the commissioners. Id. art 2, § 2.2.

${ }^{43}$ See, e.g., D.C. CODE § 3-1432 (2012); IDAHO CODE § 67-1701 (2018); OR. REV. STAT. § 172.010 (2017); VT. STAT. ANN. tit. 2, § 201 (2016); WASH. REV. CODE $\S 43.56 .010$ (2009).

${ }^{44}$ CONSTITUTION, supra note 37 , art. 2 , $\S 2.3$. Furthermore, life-members who rendered a special service to the Uniform Law Commission in the past may be appointed. Id. art. 2, § 2.4. For a good summary of the appointment and working procedures, see James W. Day, The National Conference of Commissioners on Uniform State Laws, 8 UNIV. FLA. L. REV. 276, 278 et seq. (1955).

${ }^{45}$ CONSTITUTION, supra note 37 , art. 2 , § 2.5 .

${ }^{46}$ Ziegel, supra note 1, at $137 \mathrm{f}$.

${ }^{47}$ CONSTITUTION AND ByLAWS, supra note 39

${ }^{48}$ Hurlburt, supra note 6, at 247 f.; Close, supra note 6, at 546.
} 
of a "Civil Section," a "Criminal Section," and a "Drafting Section."49 The Canadian conference focuses particularly on the harmonization of commercial law. ${ }^{50}$ Unlike in the U.S., the delegations are predominantly staffed by government lawyers from the ranks of legislative counsel and lawyers who are active in the policy development branch of their respective ministries. ${ }^{51}$ The executive heads of the law reform bodies in the different jurisdictions are usually appointed as commissioners. ${ }^{52}$ In addition, the Deputy Attorney General or the Minister of Justice are invited to participate. ${ }^{53}$ Furthermore, the federal government plays a very active role in the conference's work. ${ }^{54}$ Thus, as compared to its counterpart in the U.S., there is a higher degree of interfederal intertwining of the executive branches institutionalized within the Uniform Law Conference of Canada.

Both Uniform Law Conferences produce different kinds of draft bills: "Uniform State Acts," which are meant for wholesale implementation; and "Model State Acts," which may be further modified and adopted according to the needs of the various federal states so long as the main purposes of the act are accomplished. ${ }^{55}$ Furthermore, in Canada, the Uniform Law Conference may also draft statements on legal principles or other relevant documents. ${ }^{56} \mathrm{~A}$ yearly National Conference meets to decide on the legislative proposals. In preparation for these conferences, several permanent and nonpermanent committees work in the background. ${ }^{57}$ Nonetheless, the level of transparency varies between the U.S. Uniform Law Commission and the Canadian Uniform Law Conference. In the U.S., if the Uniform Law Commission decides to draft a uniform legislative proposal, a drafting committee is created, ${ }^{58}$ which is generally open to the public. Accordingly, representatives of interest groups or individuals may attend as observers. They do not have the right to vote, but may participate by submitting comments and suggestions. ${ }^{59}$ Any legislative proposal must be

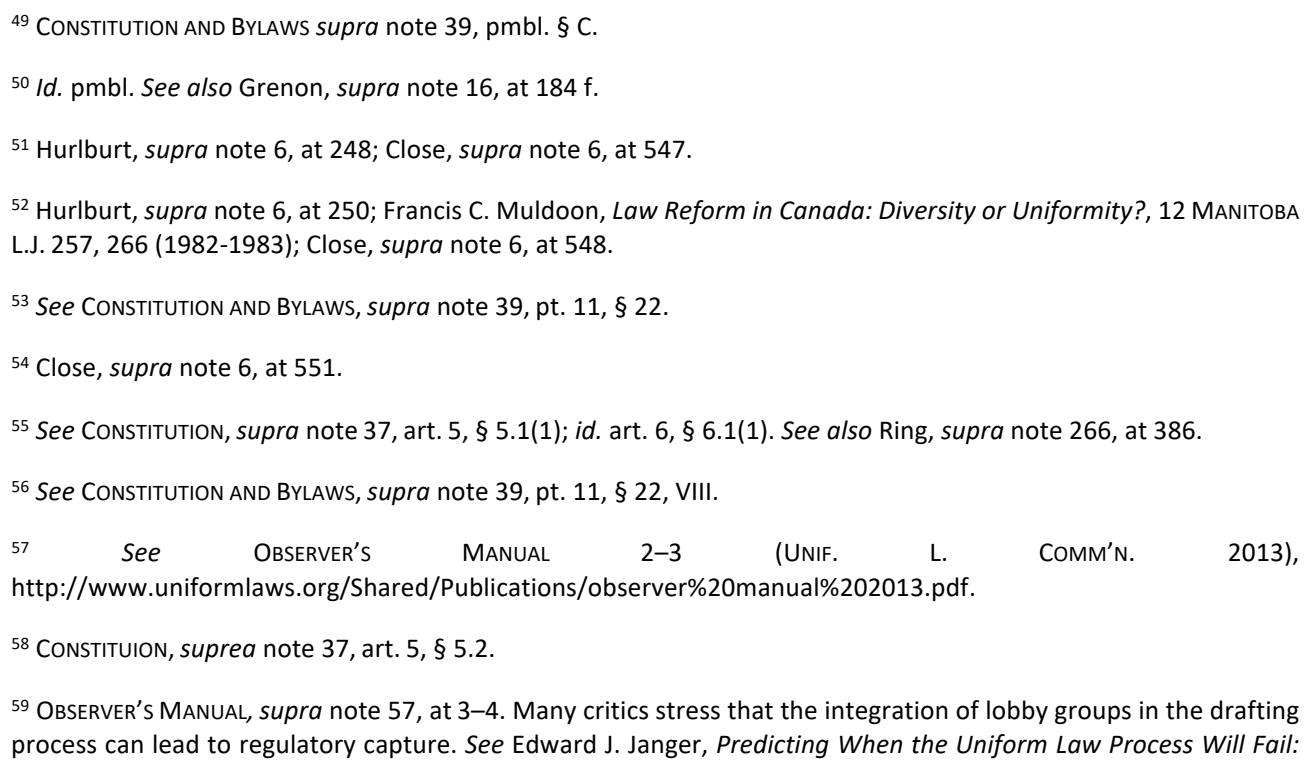


considered section-by-section during the National Conference before it can be approved during the following conference ${ }^{60}$ by the majority of the attending states casting at least 20 votes in favor of adopting the proposal. ${ }^{61}$ The adopted uniform and model state acts are published on the Uniform Law Commission website. The commissioners are then obliged to promote the enactment of the adopted legislation in their states. ${ }^{62}$ Unlike its U.S. counterpart, the constitution and bylaws of the Uniform Law Conference of Canada do not allow lobby groups or interested individuals to participate in the drafting section or to attend the annual conference. Observers are only admitted if they are invited by the conference or their committees in accordance with the aims of the conference. ${ }^{63}$ The meetings of the conference are also not open to the public. ${ }^{64}$ Hence, the working procedure in Canada is less transparent. Nevertheless, all acts, committee reports, minutes, and resolutions are published on the website of the Uniform Law Conference. ${ }^{65}$

Overall, the Uniform Law Conference of Canada is more successful than the U.S. Uniform Law Commission when it comes to implementation rates. ${ }^{66}$ This is conceivably the result of the "bureaucratic capture" of the Canadian conference, which intertwines its work into the overall political process, thereby enhancing its authority. Many of the proposed acts have been implemented in more than half of the constituting jurisdictions ${ }^{67}$ The proposals of the conference which form part of its "Commercial Law Strategy" were particularly successful. ${ }^{68}$

Article 9, Capture and the Race to the Bottom, 83 lowa L. ReV. 569, 578 et seq. (1998); ERIK P.M. VermeULen, THE EVolution of LEGal Business Forms IN EUROPE AND tHe UNITED STATES: VENTURE CAPITAL, JoINT VeNTURE AND PARTNERSHIP STRUCTURES 168 (2003).

${ }^{60}$ Constitution, supra note 37 , art. 8, § 8.1.

${ }^{61} /$ d. art. 8, §§ 8.1, 8.3.

62 Id. art. $6, \S 6.1(6)$.

63 See Rules of Procedure 1.3 (Unif. LaW Conf. CAN., Criminal Section 2013), http://www.ulcc.ca/images/stories/2013_pdfs_en/2013ulcc0034.pdf. For the annual plenary meetings, see Release of Uniform Law Conference Documents, UNIF. LAW Conf. CAN., http://www.ulcc.ca/en/about-us-en-gb1/release-of-conference-documents (last visited Nov. 11, 2018). In the Commercial Law Strategy of the Civil Section, however, there has been an extensive stakeholder involvement. See Civil Section Commercial Law Strategy, UnIF. LAW CONF. CAN., http://www.ulcc.ca/en/civil-section/27-civil-section-commercial-law-strategy (last visited Nov. 11, 2018).

${ }^{64}$ See Release of Uniform Law Conference Documents, supra note 53.

${ }^{65}$ In the past, the proceedings of the Conference have been printed and published by the Canadian Bar Association. Hurlburt, supra note 6, at 250 .

${ }^{66}$ Grenon, supra note 16 , at 184 .

67 See APPENDIX D: ULCC TABles 131 tbl. 3 (UNIF. LAW CONF. CAN. 2013), http://www.ulcc.ca/images/stories/2013_pdfs_en/2013ulcc0045.pdf.

${ }^{68}$ Close, supra note 6, at 554. 
Among other legislative areas, it encompasses the sale of goods, secured transactions, investment securities, electronic commerce, and intellectual property. ${ }^{69}$ All the same, there are still numerous proposals which have been completely ignored by the provinces. ${ }^{70}$ This can partly be explained by the varying attendance rates of the attorneys general. ${ }^{71}$

With increasing centralization in the U.S., the success rates of the Uniform Law Commission, which were very low in the beginning, have also increased. The Uniform Law Commission was particularly successful in the fields of commercial law ${ }^{72}$ and family law. ${ }^{73}$ With regard to international family law conventions, the Uniform Law Commission even achieved legal harmonization throughout the federal legal landscape that enabled subsequent ratification. ${ }^{74}$ This serves as a good example of how interfederal legal harmonization preserves the legislative freedom of the states. The states harmonized their laws freely, without federal preemption. ${ }^{75}$ Nevertheless, the overall success rates of the Uniform Law Commission are still modest. ${ }^{76}$ Only about $10 \%$ of the various Uniform and Model State Acts have been adopted by 40 or more states. ${ }^{77}$ More than half of the proposed acts were ignored by the majority of the states. ${ }^{78}$ Another weakening factor of the Uniform Law Commission in the U.S. is that private organizations such as the American Law Institute, ${ }^{79}$ the American

${ }^{69}$ Grenon, supra note 16 , at 184.

${ }^{70}$ Cf. APPENDIX D: ULCC TABLES, supra note 67, at 143 tbl. 5.

${ }^{71}$ See Ziegel, supra note 1, at 149.

72 See, e.g., U.C.C. (AM. LAW INST. \& UNIF. LAW COMM'N 1977); UNIFORM PARTNERSHIP ACT (UNIF. LAW COMM'N 2013). Cf. Stein, supra note 10 , at 2258 et seq.

73 See, e.g., UnIFORM PARENTAGE ACt (UNIF. LAW COMM'N 2017); UNIFORM CHILD CUSTOdY JURISDICTION AND ENFORCEMENT ACT (UNIF. LAW COMM'N 1997); UNIFORM INTERSTATE FAMILY SUPPORT ACT (UNIF. LAW COMM'N 2008).

74 Namely the Convention on the International Recovery of Child Support and Other Forms of Family Maintenance, Hague Conference on Private International Law, Nov. 23, 2007, https://assets.hcch.net/docs/14e71887-0090-47a39c49-d438eb601b47.pdf.

75 Furthermore, this encourages non-self-executing international agreements to preserve as much legislative autonomy of the states as possible. Instead, the ULC encourages cooperative legal harmonization to implement international law. See William H. Henning, The Uniform Law Commission and Cooperative Federalism: Implementing Private International Law Conventions Through Uniform State Laws, 2 ELON L. REV. 39, 41 et seq. (2011). See also Ring, supra note 26, at 394 et seq.

${ }^{76}$ Some Uniform and Model Acts are very successful whilst others receive no or very little attention in the states. For a description of the success rates in the different decades, see GRAVES, supra note 1, at 292; Overby, supra note 26, at 346; Mary Whisner, There Oughta Be A Law-A Model Law, 106 L. LIBR. J. 125, 127 (2014).

77 James J. White, Ex Proprio Vigore, 89 MiCH. L. ReV. 2096, 2103 et seq. (1991); Maxeiner, supra note 15, at 509.

78 GRAVES, supra note 1, at 46 et seq.; Maxeiner, supra note 15, at 509.

79 THE AMERICAN LAW INSTITUTE, https://www.ali.org/about-ali/ (last visited Nov. 11, 2018) (noting that the ALI was founded in 1923). See GRAVES, supra note 1, at 52-67. 
Legislative Exchange Council, ${ }^{80}$ and various lobby groups also try to further their legislative goals at the state level by preparing model acts. ${ }^{81}$ Thus, the interfederal legal harmonization in the U.S. is to some extent polycentric. ${ }^{82}$ Succesful implementation is dependent on external incentives-for instance, the threat that the federal level might take over a certain competence by preemptive legislation. ${ }^{83}$ Even in those cases where the majority of states implement bills of the Uniform Law Commission, the harmonization process as a whole takes a comparatively long time, making unified law reform very difficult. ${ }^{84}$

\section{Legal Harmonization by Executive Intergovernmental Conferences}

Particularly in more centralized cooperative federal systems, interfederal legal harmonization is not promoted through special Uniform Law Conferences, which are mainly run by lawyers, but rather effectuated by responsible ministers and executive senior officials in informal meetings. To exemplify this mode of interfederal legal harmonization, the intergovernmental conferences of Germany and Austria will be analyzed in the following subsection. Germany and Austria have an interconnected history and represent far more centralized federal systems than the North American federations. Furthermore, both federal systems can be described as cooperative.

\section{Overview of the Cooperative Federal Systems in Germany and Austria}

Germany and Austria can both be classified as semi-parliamentary systems with a parliamentary elected government and a president who plays more of a representative role. ${ }^{85}$ Furthermore, both constitutions provide for a bicameral system with one chamber representing the states. Yet, an important distinction can be drawn with regard to the second chamber, called the Federal Council (Bundesrat). In Austria, the parliaments of the states elect its members; ${ }^{86}$ in Germany, they are elected by the states' governments. ${ }^{87}$ The

\footnotetext{
${ }^{80}$ AMERICAN LegISLATIVe EXCHANGe CounCIL, https://www.alec.org/about/ (last visited Nov. 11, 2018) (noting that the American Legistlative Exchanage Council was founded in 1973).

${ }^{81}$ Whisner, supra note 76 , at 128; Maxeiner, supra note 15 , at $508 \mathrm{f}$.

${ }^{82}$ Cf. GRAVES, supra note 1, at 72; ANDERSON, supra note 27, at 93.

${ }^{83}$ Cf. White, supra note 77 , at 2133.

${ }^{84} \mathrm{Cf}$. Overby, supra note 26 , at 346.

${ }^{85}$ For the Austrian Federal President, see ANNA GAMPER, LegISLATIVE AND EXECUTIVE GovernANCE IN AuSTRIA 9 (2004). For an elaborative comparison of the role and the functions of the German and the Austrian presidents, see LUTZ Mehlhorn, Der Bundespräsident der BundesRepublik Deutschland und der RePUBlik ÖSterreich 468 et seq. (2010).

${ }^{86}$ Bundes-VerfassungsgeSETZ [B-VG] [CONSTITUtION] art. 35, para. 2 (Austria).

${ }^{87}$ GRUNDGESETZ [GG] [BASIC LAW], art. 51, para. 1 (Ger.).
} 
German Federal Council has a veto power regarding various fields of legislation affecting the states' interest. Therefore, it has the important political function of representing the states at the federal level and mediating federal and state interests. The Austrian Federal Council, in contrast, plays a relatively weak role in constitutional reality. ${ }^{88}$

Both federal systems have their roots in pre-constitutional sovereign states ${ }^{89}$ Nonetheless, in both nations, a strong national identity grew over time, ${ }^{90}$ which tragically culminated in the authoritarian centralized state created by Adolf Hitler and the Nazi regime. ${ }^{91}$ Thus, the federal system of the post-war constitution in Germany had no uniting purpose. It served rather as a means to break the centralized and authoritarian impetus through a territorial division of powers in order to re-democratize and re-diversify the country. ${ }^{92}$ Austria was also re-federalized after 1945. Regardless, the federal level remained prominent under the new constitution. ${ }^{93}$ Today, Germany consists of 16 states and Austria consists of nine states which are, in both countries, called Länder.

With regard to legislative and administrative competencies, there is an important distinction in both constitutional systems. In Germany, the federal level is predominantly responsible

${ }^{88}$ Anna M. Gamper \& Bernhard A. Koch, Federalism and Legal Unification in Austria, in FederalISM AND LeGAL UNIFICATION: A COMPARATIVE EMPIRICAL INVESTIGATION OF TWENTY SYSTEMS 103, 112 (Daniel Halberstam \& Mathias Reimann eds., 2014); Theo Öhlinger, Die Bedeutung von Koordination und Kooperation im System des österreichischen Föderalismus-Allgemeine Einschätzung und Ausblick in die Zukunft, in KOOPERATIVER FöDERALISMUS IN ÖSTERREICH 19, 22 (Peter Bußjäger ed., 2010).

${ }^{89}$ For the German federal system, see Wolfgang Graf Vitzthum, Die Bedeutung gliedstaatlichen Verfassungsrechts in der Gegenwart, in 46 VeRÖFFENTLICHUNGEN DER VEREINIGUNG DER DEUTSCHEN STAATSRECHTSLEHRER 7, 18 (1988). For the Austrian federal system, see Felix ERMACORA, ÖsterreichisCHER Föderalismus 29 et seq. (1976).

90 For German federalism, see Thomas Froese, Die ENTFESSELUNG des StAATES: EINE FöderalismusReform für MeHR HANDLUNGSFREIHEIT 11 (2007). For the historic development of the Austrian federalism, see ERMACORA, supra note 899 , at 27 et seq.

${ }^{91}$ For a brief overview of the history of German federalism, see MICHAEL BOTHE, DIE KOMPETENZSTRUKTUR DES MODERNEN BUNDESSTAATES IN RECHTSVERGLEICHENDER SICHT 62 (1977). For a brief description of the impacts of the Nazi regime on Austrian federalism, see ERMACORA, supra note 89, at 74.

92 Especially in Germany, the re-federalization was an important concern of the occupying forces. See ERNST DEUERLEIN, FödERALISMUS: DIE HISTORISCHEN UND PHILOSOPHISCHEN GRUNDLAGEN DES FÖDERATIVEN PRINZIPS 230 et seq. (1972); Josef Isensee, Der Föderalismus und der Verfassungsstaat der Gegenwart, 115 AÖR 248, 253 (1990); HEIDRUN ABROMEIT, DER VERKAPPTE EINHEITSSTAAT 37 et seq. (1992). For the position of the occupying forces, see also the potsdam agreement: Protocol of the Proceedings, August 1, 1945 pt. A, no. 9, https://www.nato.int/ebookshop/video/declassified/doc_files/Potsdam\%20Agreement.pdf; Frankfurt Documents of the London 6-Power Conference, reprinted in QUELLEN ZUM STAATSRECHT DER NEUZEIT II 197 et seq. (Huber ed. 1951). For a detailed explanation of the federal model of the German Constitution, see CHRISTA-MARIA LAMBRECHT, DIE FUNKTION DES FöDERALISMUS IM VERFASSUNGS-UND REGIERUNGSSYSTEM DER BUNDESREPUBLIK DEUTSCHLAND 14 et seq. (1975).

${ }^{93}$ ERMACORA, supra note 89, at 79. 
for creating legislation while the states are responsbile for its execution. ${ }^{94}$ Therefore, both levels are dependent on one another in many areas of law. ${ }^{95}$ The federal system of Germany is thus characterized by a close interweaving of the federal and the state level. ${ }^{96}$ In Austria, there is also a distinction between the legislative and the executive competencies. Article 10 of the Austrian Constitution, however, also assigns some joint competencies to the federal level. Neverthless, many important competencies listed in Article 11 of the Constitutionsuch as citizenship and housing policy-are assigned to the federal level for legislation drafting while the states are responsible for its execution.

Both systems are far more centralized than the North American federations. The German Constitution has a long list of federal and concurrent competencies. ${ }^{97}$ Furthermore, the "welfare state principle" 98 is enshrined in the German Constitution and is based on the idea of "equivalent living conditions throughout the federal territory" and the "maintenance of legal or economic unity." These constitutional values have led to a high level of centralization in constitutional reality as well as a strong incentive for interfederal cooperation and legal harmonization. ${ }^{100}$ Despite recent trends to unravel the various intergovernmental ties in Germany, ${ }^{101}$ a strong desire for legal unity remains. Interfederal

\footnotetext{
${ }^{94}$ See Christian Waldhoff, Federalism - Cooperative Federalism Versus Competitive Federalism, in DEBATES IN GERMAN PUBLIC LAW 117, 121 et seq. (Hermann Pünder \& Christian Waldhoff eds., 2014). From a political science perspective, see Scharpf, The Joint Decision Trap: Lessons From German Federalism and European Integration, 66 PUBLIC ADMINISTRATION (1988) 239, 244 et seq.

95 Scharpf, supra note 94, at 244 et seq. See also Fritz W. Scharpf, Theorie der Politikverflechtung, in PolitikVERFLeCHTUNG: THEORIE UND EMPIRIE DES KOOPERATIVEN FödeRALISMUS IN DER BUNDESREPUBLIK 13, 19 (Fritz W. Scharpf, Bernd Reissert \& Fritz Schnabel eds., 1976).

${ }^{96}$ Fritz Schnabel, Politik ohne Politiker, in POLITIK IM DICKICHT DER BÜROKRATIE 49, 50, 52 (Hellmut Wollmann ed., 1980); AвROMEIT, supra note 92 , at 9 .

97 See GRUNDGESETZ [GG] [BASIC LAW], art. 73-74 (Ger.).

${ }^{98}$ See id. art. 20(1), 28(1).

${ }^{99}$ Cf. id. art. $72(2)$.

${ }^{100}$ Waldhoff, supra note 94, at 117 et seq.; Scharpf, supra note 94, at 247; KONRAD HESSE, DER UNITARISCHE BUNDESSTAAT 19 (1962); Gyde Maria Bullinger, Die Zuständigkeit der Länder zur Gesetzgebung, 1970 DÖV 761, 762; Gerhard Lehmbruch, Der unitarische Bundesstaat in Deutschland, in FÖDERALISMUS: ANALYSEN IN ENTWICKLUNGSGESCHICHTLICHER UND VeRgleichender PeRSPEKTIVE 53, 103 (Arthur Benz \& Gerhard Lehmbruch eds., 2002); ANNE HOHLER, KompetiTION STATT KOOPERATION - EIN MODELl ZUR ERNEUERUNG DES DEUTSCHEN BUNDESSTAATES? 80 et seq. (2009).

${ }^{101}$ For these claims, see Scharpf, supra note 94, at 247 et seq.; Hartmut Klatt, Parlamentarisches System und bundesstaatliche Ordnung, 31 APuZ 3, 21 (1982) [hereinafter Klatt, Parlamentarisches System und bundesstaatliche Ordnung]; Hartmut Klatt, Interföderale Beziehungen im kooperativen Bundesstaat, 78 VERWALTUNGSARCHIV 186, 202 et seq. (1987) [hereinafter Klatt, Interföderale Beziehungen im kooperativen Bundesstaat]; THOMAS FROESE, DIE ENTFESSELUNG DES STAATES 43 et seq. (2007). For criticism of further unraveling of the cooperative structures in Germany, see Arthur Benz, Lehren aus entwicklungsgeschichtlichen und vergleichenden Analysen-Thesen zur
} 
legal harmonization has therefore enjoyed a steady and unbroken history in Germany. ${ }^{102}$ In Austria, there is also a strong drive for centralization and a close historical interdependence between the different governmental levels. ${ }^{103}$ The desire to create uniform living conditions throughout the country is also deeply rooted in the Austrian society. ${ }^{104}$ Austria, therefore, serves as a prime example of cooperative federalism. ${ }^{105}$ The informal intergovernmental conferences of the Austrian states (Landeshauptleutekonferenzen), which will be analyzed in the following subsection, have assumed an important political function in constitutional reality and are recognized as an even more powerful forum for the states than the German Federal Council. ${ }^{106}$

\title{
II. Intergovernmental Conferences in Germany and Austria
}

Interfederal legal harmonization is achieved by various executive intergovernmental conferences in Germany and Austria. The highest level of coordination takes place at the governors' conferences-the Ministerpräsidentenkonferenz ${ }^{107}$ in Germany and Landeshauptleutekonferenz ${ }^{108}$ in Austria. As mentioned above, in Austria this institution has

aktuellen Föderalismusdiskussion, in FöDERALISMUS: ANALYSEN IN ENTWICKLUNGSGESCHICHTLICHER UND VERGLEICHENDER Perspektive 391, 392 et seq. (Arthur Benz \& Gerhard Lehmbruch eds., 2002).

102 Cf. ABRomeit, surpa note 92, at 8, 70; RÜdiger GÖRNER, EINHEIT DURCH Vielfalt: FöderalisMUS ALS POLITISCHE LEBENSFORM 205 (1996); BIRGIT OLdOPP, UNIFORME STANDARDS, KOMPETENZERWEITERUNGEN UND VETOMÖGLICHKEITEN 21 (2012).

103 GAMPER, supra note 85, at 20 et seq.; Öhlinger, surpa note 88, at 19 et seq. For a brief characterization of the federal system in Austria, see TAYLOR, supra note 30, at 95 et seq.

${ }^{104}$ Cf. ERMACORA, supra note 89, at 80 et seq.; PETER BUßJÄGER, Intergouvernementale Beziehungen in Österreich und politische Entscheidungsprozesse, in KOOPERATIVER FÖDERALISMUS IN ÖSTERREICH 121, 125 (2010).

105 GAMPER, supra note 85, at 22; BUßJÄGER, supra note 104, at 121 et seq.

${ }^{106}$ Cf. Gamper \& Koch, supra note 88, at 112.

107 The Ministerpräsidentenkonferenz is a more informal body. All the same, Section 31 of the Rules of Procedure of the Federal Government provides that:

\begin{abstract}
The presiding members of the states' governments are to be invited several times a year for joint discussions with the federal government by the Federal Chancellor in order to discuss important political, economic, social and financial questions and to contribute in a personal way to an understandable uniform policy in the federal and state governments.
\end{abstract}

See HANS-THOMAS KNOKE, Die KULTUSMINISTERKONFERENZ UND DIE MINISTERPRÄSIDENTENKONFERENZ 109 et seq. (1966).

108 The Austrian Landeshauptleutekonferenz is even mentioned in the constitution. BUNDES-VERFASSUNGSGESETZ [BVG] [CONSTITUTION], art. 59b(1) (Austria). Several other laws make a similar reference. See Andreas Rosner \& Robert Gmeiner, Die Länderkonferenzen als Instrumente der Selbstkoordination der Länder und des kooperativen Bundesstaats, in KOOPERATIVER FÖdERALISMUS IN ÖSTERREICH 49, 52 (Peter Bußjäger ed., 2010). 
a huge political impact. These intergovernmental conferences not only focus on the harmonization of state laws, but also serve a more general coordinating function. ${ }^{109}$

In both countries, the substantive discussions in the different policy areas are dealt with by independent ministerial conferences-Ministerkonferenzen in Germany and Landesreferentenkonferenzen and Landesexpertenkonferenzen in Austria-which are manned with ministers of the states and senior officials. Thus, instead of one conference that discusses model acts for all areas of state law, intergovernmental conferences have evolved to work independently in their particular fields of expertise and meet several times a year. ${ }^{110}$ In contrast to the Uniform Law Conferences, the intergovernmental conferences usually only prepare documents with political guidelines and objectives for future legal

109 Rules of Procedure, BAUMINISTERKONFERENZ [ARGEBAU], https://www.bauministerkonferenz.de/dokumente/Geschaeftsordnung.pdf (last visited Nov. 20, 2018) (providing the Rules of Procedures for the German Construction Minister's Conference (Bauministerkonferenz)); Rules of Procedure, GeRman CONFERENCE of THE Ministers of Educ. AND CULTURAL AFFAIRS, KULTUSMINISTERKONFERENZ [KMK], https://www.kmk.org/ (last visited Nov. 20, 2018) (providing the preamble for the Rules of Procedure for the German Conference of the Ministers of Education and Cultural Affairs (Kultusministerkonferenz)). For the Austrian conferences, see GAMPER, supra note 85, at 22.

110 In Germany the following 19 ministerial conferences exist: Conference of the Agriculture Ministers (Agrarministerkonferenz, AMK); Conference of the Social and Employment Ministers (Arbeits- und Sozialministerkonferenz, ASMK); Conference of the Building Ministers (Bauministerkonferenz, ARGEBAU); Conference of the Ministers of Europe (Europaministerkonferenz, EMK); Conference of the Finance Ministers (Finanzministerkonferenz, FMK); Conference of the Ministers of Science (Gemeinsame Wissenschaftskonferenz, GWK); Conference of the Ministers of Health (Gesundheitsministerkonferenz, GMK); Conference of the Ministers for Gender Equality (Konferenz der Gleichstellungs- und Frauenminister der Länder, GFMK); Conference of the Ministers of the Interior (Innenministerkonferenz, IMK); Conference of the Ministers of Integration (Integrationsministerkonferenz, IntMK); Conference of the Ministers for Youth and Family (Jugend- und Familienministerkonferenz, JFMK); Conference of the Ministers of Justice (Justizministerkonferenz, JuMiKo); Conference of the Ministers of Education and Cultural Affairs (Kultusministerkonferenz, KMK); Conference of the Ministers for Spatial Planning (Ministerkonferenz für Raumordnung, MKRO); Conference of the Ministers of Sports (Sportministerkonferenz, SMK); Conference of the Environment Ministers (Umweltministerkonferenz, UMK); Conference of the Ministers for Consumer Protection (Verbraucherschutzministerkonferenz, VSMK); Conference of the Ministers of Transport (Verkehrsministerkonferenz, VMK); Conference of the Ministers of Economy (Wirtschaftsministerkonferenz, WMK). Of course, not all states have 19 ministries, and thus often the state ministers take part in two or more ministerial conferences. In Austria, the names of the Conferences vary according to the competencies of the states' ministers. In the past, there have been the following conferences: Conference of the Speakers of Agricultural Matters (Landesagrarreferentenkonferenz); Conference of the Speakers of Family Matters (Landesfamilienreferentenkonferenz); Conference of the Speakers of Finance (Landesfinanzreferentenkonferenz); Conference of the Speakers for Health (Landesgesundheitsreferentenkonferenz); Conference of the Speakers of Youth Matters (Landesjugendreferentenkonferenz); Conference of the Speakers of Cultural Matters (Landeskulturrefrentenkonferenz); Conference of the Experts on Social Matters (Landessozialreferentenkonferenz); Conference of the Speakers of Sports (Landessportreferentenkonferenz); Conference of the Speakers of Environmental Matters (Landesumweltreferentenkonferenz); Conference of the Speakers of Traffic (Landesverkehrsreferentenkonferenz). For the functions of the Austrian conferences see, Rosner \& Gmeiner, supra note 108 , at 51. 
development instead of model laws. ${ }^{111}$ The political resolutions of the intergovernmental conferences are then to be transformed into state laws at the state level. ${ }^{112}$

The intergovernmental conferences are institutionalized neither by the Constitution nor by sub-constitutional law. The majority of the conferences do not even provide any kind of written procedural rules. They operate informally on the basis of unwritten codes of practice that have evolved over time and are therefore highly flexible in their application. ${ }^{113}$ In Germany, only seven of the 19 ministerial conferences have written procedural rules which are then published on their respective websites. In Austria, the states have founded a "liaison office of the states" (Verbindungsstelle der Bundes/änder) which has adopted rules of procedure that set out a few basic rules for the governors' and ministerial conferences. ${ }^{114}$ Most importantly, these set of rules stipulate that the Austrian interfederal conferences must decide unanimously on their resolutions. ${ }^{115}$ In Germany, the vast majority of the conferences also reach decisions by a unanimous vote. ${ }^{116}$ Still-as an important exceptionthe German Ministerial Conference of Education and Arts (Kultusministerkonferenz) only requires a qualified majority vote. ${ }^{117}$ In one-third of the Austrian ministerial conferences ${ }^{118}$ and in more than half of the German ministerial conferences, the respective federal minister

\footnotetext{
111 For the German ministerial conferences, see PaUl Georg SCHNeIder, Beteiligung Der LandeParlamente Beim ZUSTANDEKOMMEN VON STAATSVERTRÄGEN UND VERWALTUNGSABKOMMEN DER BUNDESLÄNDER 11 (1978). For the Austrian ministerial conferences, see Rosner \& Gmeiner, supra note 108, at $56 \mathrm{f}$.

${ }^{112}$ For an example of the resolutions of the German ministerial conferences, see Detailed Specifications for the Final School Exams (Abitur) of the Conference of the Ministers of Education and Cultural Affairs (Kultusministerkonferenz), KULTUSMINISTERKONFERENZ https://www.kmk.org/dokumentation-statistik/beschluesse-undveroeffentlichungen/bildung-schule/allgemeine-bildung.html\#c1284 (last visited Nov. 20, 2018).

113 See Klatt, Interföderale Beziehungen im kooperativen Bundesstaat, supra note 101, at 189; Walter Rudolf, Kooperation im Bundesstaat, in VI HANDBUCH DES STAATSRECHTS § 141, para. 41 et seq. (Josef Isensee \& Paul Kirchhof eds., 3d ed. 2008).

114 The Rules of Procedure of the Joint Interfederal Bureau (Geschäftsordnung der Verbindungsstelle der Bundes(änder, GO-VSt) can be found as an annex in GERNOT MEIRER, DIE VERBINDUNGSSTELLE DER BUNDESLÄNDER ODER DIE GEWERKSCHAFTLICHE ORGANISIERUNG DER LÄNDER (2003).

${ }^{115}$ Rules of Procedure of the Joint Interfederal Bureau § 7, supra note 114.

${ }^{116}$ For a critical analysis of the unanimous decision making with regard to efficiency, see Scharpf, supra note 33, at 848 et seq.

${ }^{117}$ According to Section A.I.6 of the Rules of Procedure of the German Conference of the Ministers of Education and Cultural Affairs (Kultusministerkonferenz) (KMK), a unanimous vote is only necessary for certain issues of significant importance. Other than that, a majority of 13 out of 16 votes is sufficient. See GESCHÄFTSORDNUNG DER KMK, https://www.kmk.org/fileadmin/Dateien/pdf/KMK/GO-GR-Fassung-29-08-2014.pdf (last visited Nov. 20, 2018). In the Conference of the Ministers for Consumer Protection (VSMK), a majority of 13 votes is always sufficient. See GESCHÄFTSORDNUNG DER VSMK, https://www.verbraucherschutzministerkonferenz.de/VSMKDokumente-Geschaeftsordnung.html (last visited Nov. 20, 2018).

118 Rosner \& Gmeiner, supra note 108 , at 61.
} 
is also invited. ${ }^{119}$ In the German ministerial conferences, he is usually treated as a permanent guest who may take the floor but who has no vote in the actual decision-making process. ${ }^{120}$ Considering the complexity of some of the issues considered by the ministerial conferences in Germany, there exists an important bureaucratic substructure consisting of working groups and committees that are run by senior officials of the ministerial bureaucracy. ${ }^{121}$ In Austria, the interfederal conferences are supported by "state expert conferences" (Länderexpertenkonferenzen) staffed by senior officials working in the respective ministries who resolve "recommending decisions" (empfehlende Beschlüsse) in order to inform and advise the ministerial and governors' conferences. ${ }^{122}$ Citizens, interest groups, or experts do not enjoy participation rights. In exceptional circumstances, the conferences or their subsidiary committees invite external parties such as NGOs or expert groups. ${ }^{123}$

With regard to producing outcomes, the intergovernmental conferences in Germany and Austria are very successful. Although the resolutions have no binding legal effects, the intergovernmental conferences have strong political influence over legislation in the states. ${ }^{124}$ Due to the political power of the ministers and the parliamentary system that

119 In the Ministerial Conference of Education and Arts (KMK) and the Conference of the Ministers of Sports (SMK), however, only the state ministers are invited.

${ }^{120}$ This is true for the Ministerial Conference of Agriculture (Agrarministerkonferenz, AMK) - specifically, Section 1.4 of the Rules of Procedure of the Ministerial Conference of Agriculture-and for the Conference of the Ministers of the Interior (Innenministerkonferenz, IMK). See GESCHÄFTSORDNUNG AMK, https://www.agrarministerkonferenz.de/documents/go-amk-stand-28092018_1539351169.pdf (last visited Nov. 20, 2018). See also the WEBSITE OF THE IMK, https://www.innenministerkonferenz.de/IMK/DE/aufgaben/aufgabennode.html;jsessionid=441D336BEC08BAA6A096E04B74890820.1_cid349 (last visited Nov. 20, 2018). In other ministerial conferences such as the Conference of the Ministers for Consumer Protection (VSMK), for example, the federal minister has the right to vote but resolutions may also be passed in his absence. See GESCHÄFTSORDNUNG DER VSMK, https://www.verbraucherschutzministerkonferenz.de/VSMK-Dokumente-Geschaeftsordnung.html (last visited Nov. 20, 2018).

${ }^{121}$ For an example, see Rules of procedure for the German Ministerial Conference of Agriculture arts. 9-10, supra note 120; Rules of Procedure for the German Conference of the Minster of Sports art. 2, GESCHÄFTSORDNUNG SMK, http://www.sportministerkonferenz.de/sites/default/files/dokumente/Beschluss\%20der\%2039.\%20SMK_Gesch\% C3\%A4ftsordnung\%20der\%20SMK.pdf (last visited Nov. 20, 2018); Rules of Procedure for the German Conference of the Minister of the Environment $\S \S 9,10$, GESCHÄFTSORDNUNG UMK https://www.umweltministerkonferenz.de/documents/umk-go-2017_1518084108.pdf. (last visited Nov. 20, 2018). See also Klatt, Interföderale Beziehungen im kooperativen Bundesstaat, supra note 101, at 189.

122 See ANdREAS ROSNer, KOORDINATIONSINSTRUMENTE DER ÖSTERREICHISCHEN LÄNDER 128 et seq. (2000); Rosner \& Gmeiner, supra note 108 , at $56 \mathrm{f}$.

${ }^{123}$ For Austria, see $i d$. at 49,56 . The same is true for the German ministerial conferences. See Hans Schneider, Verträge zwischen Gliedstaaten im Bundesstaat, 19 VVDSTRL 1, 12 (1961).

124 Bundesverfassungsgericht [BVERFGE] [Federal Constitutional Court], June 22, 1977, 45 BVerfGE 400, 421 [hereinafter Judgment of June 22, 1977]. See also MARTIN HIRSCHMÜLLER, DIE KONFERENZEN DER MINISTERPRÄSIDENTEN UND RESSORTMINISTER DER LÄNDER IN DER BUNDESREPUBLIK DEUTSCHLAND 112 et seq. (1967); KNOKE, supra note 107, at 49-90; HERMANN EICHER, DER MACHTVERLUST DER LANDESPARLAMENTE 96 (1988). 
connects the executive and the legislative branch politically, the states' parliaments hardly ever refrain from implementing the resolutions of the interfederal ministerial conferences.

\section{Comparative Evaluation of the Legal Harmonization by Uniform Law Conferences and Executive Intergovernmental Conferences}

\section{Efficiency of Legal Harmonization}

Regarding the success rates of the interfederal harmonization of state laws, the executive intergovernmental conferences are particularly efficient because they have the political means to enforce the resolutions of the ministerial conferences. Accordingly, reforms of the harmonized laws of the states can also be effectuated in a timely manner. This method of interfederal legal harmonization will, however, often result in state laws that differ in detail as the ministerial conferences only set policy goals instead of formulating model laws. Thus, a full unification of state laws will hardly ever result from interfederal legal harmonization through executive intergovernmental conferences. Whether the Austrian or German intergovernmental institutions are achieving better results is hard to tell because the documentation of the work of these institutions is poor and their work is largely carried out informally. There is no doubt, however, that they are far more successful than the Uniform Law Conferences in North America. ${ }^{125}$ The Uniform Law Commission of the U.S. performs worst with regard to its implementation rates because the commissioners often have no effective means to guarantee that the states will implement the proposed act. Nevertheless, the U.S. Uniform Law Commission has effectuated important harmonization of laws in the area of private law. The Uniform Commercial Code is a prominent example of this success. The Canadian Uniform Law Conference performs slightly better because important officers of the states' executive branches partly staff it. Furthermore, in a parliamentary system, the executive branch has an important influence on the legislative branch, as the two branches are politically dependent upon each other. ${ }^{126}$ The success of the Canadian Uniform Law Conference is therefore, to a large extent, dependent on the level of participation and commitment of government officials who have the power to push its state and model laws through the parliaments of the provinces. ${ }^{127}$ As a result, the efficiency of the interfederal legal harmonization increases proportionate to the level of intergovernmental integration brought on by the participation of government officials and their staff.

\footnotetext{
${ }^{125}$ For the ministerial conferences in Germany, see Schneider, supra note 123, at 12 . For the efficiency of the ministerial conferences in Austria, see ROSNER, supra note 122, at 32.

${ }^{126}$ Even though the Prime Minister and his cabinet are not mentioned in the Canadian Constitutional Acts, he governs the country on the basis of a long-established legal tradition. As in all semi-parliamentary systems, he is de facto dependent upon the confidence of Parliament. Moreover, the Canadian Prime Minister is usually also a member of Parliament. For details, see HoGG, supra note 19, at $196 \mathrm{f}$.

${ }^{127}$ Cf. Ziegel, supra note 1, at 149.
} 


\section{Compatibility with Democratic Principles}

Nevertheless, intergovernmental cooperation also has its drawbacks. With regard to democratic principles, one may criticize that interfederal cooperation allows heteronomy to a certain extent if the representatives of one state may have legislative input over the law in another state. ${ }^{128}$ This undermines the democratic principle of equality between the electorate and those who hold regulatory authority over legislation. ${ }^{129}$ Creating a "third level" between the state level and the federal level through interfederal cooperation institutions allows an informal and remote form of governance that contradicts the people-oriented ideal of federalism. ${ }^{130}$ In the Uniform Law Conferences, the democratic legitimacy of the delegated lawyers is also questionable, especially as lobby groups are given more influence. ${ }^{131}$ Moreover, the intergovernmental executive cooperation in Germany, Austria, and-to a certain extent-Canada weakens the role of the parliaments of the states and provinces. ${ }^{132}$ The higher the intensity of political pressure of the harmonizing conferences, the less power the parliaments have to set their own legislative agendas. ${ }^{133}$

Still, interfederal legal harmonization is an important mechanism to prevent further centralization and is, therefore, an important way to protect federalism. ${ }^{134}$ Competencies of the states and provinces encourage an active citizenship and foster grassroots democracy. ${ }^{135}$ With this in mind, interfederal legal harmonization can guarantee a better information

\footnotetext{
128 GUNTER KISKER, KOOPERATION IM BUNDESSTAAT 118 f., 143 (1971) (arguing that that the principle of unanimous vote should be binding for the ministerial conferences). See also MARTIN HIRSCHMÜLLER, DIE KONFERENZEN DER MINISTERPRÄSIDENTEN UND RESSORTMINISTER DER LÄNDER IN DER BUNDESREPUBLIK DEUTSCHLAND 79 (1976).

${ }^{129}$ KISKER, supra note 128 , at 143.

${ }^{130}$ Id. (providing the German perspective). From the US-American perspective, see Greve, supra note 29 , at 562.

131 Maxeiner, supra note 15, at 509.

132 HESSE, supra note 100, at 20; LAMBRECHT, supra note 92, at 246; SCHNEIDER, supra note 111, at 125, 138; Schnabel, supra note 966, at 62; EICHER, supra note 124, at 96. Less concerned about the effects of intergovernmental cooperation on parliaments, see ARTHUR BENZ, FÖDERALISMUS ALS DYNAMISCHES SYSTEM 37 (1985).

${ }^{133}$ Cf. Walter Leisner, Schwächung der Landesparlamente durch grundgesetzlichen Föderalismus, 1968 DÖV 389 , 392 (1968); SCHNEIDER, supra note 111, at 118 et seq.; Martin Morlock, Informalisierung und Entparlamentarisierung politischer Entscheidungen als Gefährdungen der Verfassung?, 62 VVDSTRL 39, 44 f. (2003); KISKER, supra note 128, at 123 et seq., 143.

${ }^{134}$ For the North American perspective, see GRAVES, supra note 1, at 29, 289, 304; Heimanson, supra note 26 , at 165 et seq.; David W. Leebron, Claims for Harmonization: A Theoretical Framework, 27 CAN. BUS. L.J. 63, 104 (1996); Erwin Chemerinski et al., Cooperative Federalism and Marijuana Regulation, 62 UCLA L. REV. 74, 116 (2015). For the German and Austrian perspective, see WolfGANG ABENDROTH, DAS GRUNDGESETZ 915 (5th ed. 1975); Öhlinger, supra note 88 , at 22; OLDOPP, supra note 102 , at 17 et seq.

135 HESSE, supra note 100, at 29 et seq.; ABENDROTH, supra note 134, at 91 f.; Arthur Benz, Neue Formen der Zusammenarbeit zwischen den Ländern, 1993 DÖV 85, 87 (1993); HOHLER, supra note 100, at 57.
} 
retrieval than federal legislation because it allows for regional peculiarities to be considered in the interfederal harmonization process. ${ }^{136}$ Nevertheless, the informal procedures of the intergovernmental cooperation in Canada, Germany, and Austria all exclude the public to a great extent. The participatory procedural rules of the U.S. Uniform Law Commission may thus serve as a role model for increasing the deliberative effect of federalism in the course of interfederal legal harmonization. ${ }^{137}$

Furthermore, all forms of interfederal legal harmonization are dependent on implementation by state parliaments. ${ }^{138}$ Thus, from a legal perspective, interfederal legal harmonization causes no harm to the right of self-determination of the states. ${ }^{139}$ Even taking into account the factual weakening of the parliaments as a result of the executive interfederal harmonization conferences, a strong argument against intergovernmental cooperation is untenable. In fact, the weak political agenda-setting power of the parliaments is not an effect of interfederal cooperation mechanisms, but rather a product of the parliamentary constitutional systems themselves. ${ }^{140}$ In parliamentary systems, the government is directly or indirectly elected by the parliament and dependent on its confidence. ${ }^{141}$ Because of this interrelation, the government usually consists of elites from the majority parties in parliament who have strong influence over the members of parliament through the factual "party discipline." ${ }^{\text {"142 }}$ As a result, in the semi-parliamentary systems of Germany, Austria, and Canada, bills are, as a rule, drafted by the executive and thus subject to scrutiny by the government. ${ }^{143}$ Nevertheless, in order to foster greater

${ }^{136}$ For the North American perspective, see Philip J. Weiser, Federal Common Law, Cooperative Federalism, and the Enforecement of the Telecom Act, 76 N.Y.U. L. REV. 1692, 1698 et seq. (2001). For the German perspective, see EICHER, supra note 124, at 97. For a different opinion, see HIRSCHMÜLLER, supra note 124, at 93 (arguing that federalism becomes meaningless through increasing interfederal harmonization).

137 For a broader participation of the parliaments in Germany, see KAI VON LEWINSKI, GESETZESVERFASSER UND GeSETZGEBER 67 (2015). For the opposing opinion, see HOHLER, supra note 100, at 64.

${ }^{138}$ For the system in the United States, cf. Janger, supra note 59, at 591 et seq. (expressing criticism that the unification process institutionalizes a race to the bottom because of the need to implement the proposed legislation in the states). For the German system, see Judgment of June 22, 1977, supra note 124.

${ }^{139}$ KISKER, supra note 128, at 145.

140 For a good overview of the differences between presidential and parliamentary systems, see Ronald J. Krotoszynski, The Separation of Legislative and Executive Powers, in COMPARATIVE CONSTITUTIONAL LAW 234 et seq. (Tom Ginsburg \& Rosalind Dixon eds., 2011); Jenny S. Martinez, Horizontal Structuring, in THE OXFORD HANDBOOK OF Comparative Constitutional LaW 547, 553 et seq. (Michel Rosenfeld \& András Sajó eds., 2013).

${ }^{141}$ See GRUNDGESETZ [GG] [BASIC LAW], art. 63(1), 67 (Ger.).

142 See José Antonio Cheibub \& Fernando Limongi, Legislative-Executive Relations, in ComPARATIVE ConstitutiOnAL LAW 211, 215 (Tom Ginsburg \& Rosalind Dixon eds., 2011).

${ }^{143}$ Even in the presidential system of the United States, the executive has effective means to introduce bills, even though formally only the parliament has this right. A good example of the presidential influence on legislation is the "New Deal" legislation by President Franklin D. Roosevelt. For an in depth analysis, see HERINGA \& KüVER, supra 
involvement by the parliaments of the states and provinces in the harmonization process, the participants of the executive intergovernmental institutions should inform their respective parliaments regularly and give them opportunity to submit comments. ${ }^{144}$ In the U.S., legislatures enjoy a higher degree of freedom to ignore or alter the proposals of the Uniform Law Commission. ${ }^{145}$ Additionally, due to the presidential system, with its stronger division between executive and legislative functions, an increase of senior civil servants in the commission would most likely not lead to the high efficiency of the German and Austrian ministerial conferences. As a result, with regard to interfederal legal harmonization, there is a certain trade-off between effectiveness and parliamentary freedom-and therefore democratic legitimacy.

\section{Transparency and Accountability}

Likewise, intergovernmental interfederal cooperation has been broadly criticized for certain failings in democratic principles like transparency and accountability. Law-making in ministerial conferences, which operate in the shadows and without a constitutional mandate, conceals who is responsible for the resulting norms. ${ }^{146}$ The interfederal cooperation organizations enable politics without politicians by vesting the responsibility for the harmonized laws in the hands of ministerial bureaucracy or delegated lawyers. ${ }^{147}$ This decreases party competition ${ }^{148}$ and reduces the influence of the electorate. At the same

\footnotetext{
note 12, at 95; RalPH AleXANDeR LORZ, INTERORGANRESPEKT IM VERfASSUnGSRECHT 143 (2001). For criticism of the executive prejudice of legislation in Germany, see Matthias Herdegen, Informalisierung und Entparlamentisierung politischer Entscheidungen, 62 VVDSTRL 7, 15 et seq. (2003); Martin Morlok, Informalisierung und Entparlamentisierung politischer Entscheidungen, 62 VVDSTRL 39, 44 et seq. (2003). For a critique with regard to the lack of transparency in the drafting process, see Herrmann Pünder, Wahlrecht und Parlamentsrecht als Gelingensbedingungen repräsentativer Demokratie, 72 VVDSTRL 191, 241 et seq. (2013).

144 See also Benz, supra note 135, at 94 (pleading for an extended involvement of the states' parliaments). In Germany, the states increasingly implement rules obliging the state government to inform on the results of the ministerial conferences. See - for example - Constitution of North Rhine Westphalia, art. 40 and Constitution of Rheinland-Pfalz, art. 89b.

145 GRAVES, supra note 1, at 50 et seq.; Maxeiner, supra note 15, at 509. See also NiCole BolleYeR, Paradoxes of SelfCoordination in Federal Systems, in Federal DyNAmics 321, 328 (Arthur Benz \& Jörg Broschek eds., 2013).

146 From a U.S. American perspective, see AdVISORY COMm'N ON INTERGOVERNMENTAL ReL., The Federal Role IN THE Federal System: The Dynamics of Growth 25 f. (1980); Greve, supra note 29, at 559, 567, 575. From a German perspective, see Klatt, Parlamentarisches System und bundesstaatliche Ordnung, supra note 101, at 9; ABROMEIT, supra note 102, at 52; Edzard Schmidt-Jortzig, Herausforderungen an den Föderalismus, 1998 DÖV 746, 748 (1998); REINHOLD ZiPPELIUS \& THOMAS WÜRTENBERGER, DEUTSCHES STAATSRECHT § 14, para. 69 (32d ed. 2008).

147 Schnabel, supra note 96, at 49 et seq.; Klatt, Parlamentarisches System und bundesstaatliche Ordnung, supra note 101, at 8; ZIPPELIUS \& WÜRTENBERGER, supra note 146, § 14 Rn. 71; Greve, supra note 29, at 576.

148 Gerhard Lehmbruch, PARTeienWettbewerb im BundesstaAt 162 et seq. (3d ed., 2000).
} 
time, critics argue, interfederal cooperation fosters coalition-like negotiations that inhibit innovations and decelerate decision-making processes. ${ }^{149}$

Although it is admittedly true that cooperation procedures point towards consensus rather than competition, ${ }^{150}$ political parties also play an important role in intergovernmental organizations. Especially in the German and Austrian executive intergovernmental conferences, there is an immediate political presence because of the participation of the ministers. ${ }^{151}$ In preliminary meetings, ministers from the same political party often try to reach common positions. ${ }^{152}$ Thus, the issues discussed at the ministerial conferences are indeed politicized. In two-party systems, where consensus is hard to achieve because the parties need clear demarcation, as is the case in the U.S. Uniform Law Commission, majority decisions could have an accelerating effect. ${ }^{153}$

In order to increase the transparency of these mechanisms, the discussions at the conferences should be documented and published online. ${ }^{154}$ The parliaments of the states and provinces should at the very least be continuously informed on the decision-making process. Nevertheless, decision-making decelerates as more participants become involved. ${ }^{155}$ Thus, in fields where fast decisions or where constant reforms are needed-such as in risk regulation-a transfer of competencies to the federal level more adequately guarantees more flexible and accurate legislation. ${ }^{156}$

\footnotetext{
149 Id. at 162; Scharpf, , supra note 94, at 247 et seq.; Larry E. Ribstein \& Bruce H. Kobayashi, An Economic Study of Uniform State Laws, 25 J. OF LEGAL STUD. 131, 141 (1996); Greve, supra note 29, at 562.

150 See LEHMBRUCH, supra note 148, at 29 et seq.; Hartmut Klatt, Interföderale Beziehungen im kooperativen Bundesstaat: Kooperation und Koordination auf der politischen Leitungsebene, 78 VERWALTUNGSARCHIV 186, 194 (1987).

${ }^{151}$ Klatt, supra note 150, at 199.

152 Id. at 194; STEPHAN SMith, KONFLIKTLÖSUNG IM DEMOKRATISCHEN BUNDESSTAAT 270 (2011).

${ }^{153}$ For majority votes in the German ministerial conferences, see MEINHARD ADE, DER LÄNDERRAT: ZUR ZWECKMÄßIGKEIT UND ZULÄSSIGKEIT EINER VERFASSTEN LÄNDERGEMEINSCHAFT 136 et seq. (1976). For the opposing view, see HIRSCHMÜLLER, supra note 124 , at $87 \mathrm{f}$.

${ }^{154}$ See also ADE, supra note 153 , at 36 et seq.

${ }^{155}$ ABROMEIT, supra note 102, at 49; Klatt, Parlamentarisches System und bundesstaatliche Ordnung, supra note 101, at 7.

156 See ANIKA KLAFKI, RISIKO UND RECHT 125 et seq. (2016).
} 


\section{E. Concluding Remarks}

Due to the increasing mobility of modern societies and global integration, the pressure on federations to unify state laws increases. In order to preserve federalism, and therefore prevent an ever-advancing process of centralization, interfederal legal harmonization is crucial. ${ }^{157}$ There are two distinct methods of legal harmonization of state laws: (1) the harmonization by Uniform Law Conferences, which are in principle staffed by lawyers and thus externalized to a certain extent from policy makers; and (2) the harmonization by executive intergovernmental conferences. In comparison, with regard to the implementation rates, the intergovernmental conferences are more successful due to their higher degree of political influence over the states' parliaments. In order to respond to growing criticism, the procedures of interfederal organizations promoting legal harmonization of state laws should be designed to be more transparent and allow for public participation. The constitution and bylaws of the U.S. Uniform Law Commission can serve as a role model in this respect.

\footnotetext{
${ }^{157}$ An example of just how dysfunctional nations can become if there is no interfederal cooperation can be seen in Bosnia and Herzegovina. For more details on this topic, see Venice Commission, Preliminary Opinion on the Draft Amendments to the Constitution of Bosnia and Herzegovina, CDL(2006)027; Anika Klafki, Friedenssicherung durch Verfassungsrecht, 2015 DÖV 637, 640 et seq.
} 